\title{
Disturbance of the Re-Os chronometer of molybdenites from the late-Caledonian Galway Granite, Ireland, by hydrothermal fluid circulation
}

\author{
KATSUhiKo SuZuki, ${ }^{1 *}$ MARTin FeEly ${ }^{2}$ and Cian O’ ReILly ${ }^{3}$ \\ ${ }^{1}$ Department of General Systems Sciences, Graduate School of Arts and Sciences, University of Tokyo, \\ Komaba, Meguro, Tokyo 153-8902, Japan \\ ${ }^{2}$ Department of Geology, National University of Ireland, Galway, Ireland \\ ${ }^{3}$ Navan Resources, Kennedy Rd., Navan, Co. Meath, Ireland
}

(Received March 7, 2000; Accepted November 8, 2000)

\begin{abstract}
Re-Os ages were determined for molybdenites from the late-Caledonian Galway Granite in the west of Ireland. Molybdenites from three localities within the batholith, Mace Head, Murvey, and Travore, yield respective Re-Os ages of $425.2 \pm 3.1 \mathrm{Ma}, 383.2 \pm 8.1$ and $426.1 \pm 5.5 \mathrm{Ma}$, and $338.9 \pm 5.6$ and $464 \pm 28$ Ma. The molybdenites from the three localities are believed to be contemporaneous. However, the Re-Os ages obtained for each locality are not only in disagreement with the ages of the samples from the other localities but also are inconsistent within a single locality. Replicate analyses of a molybdenite standard (HLP-5) characterized by AIRIE using our method (Suzuki et al., 1992) yields reproducible Re-Os ages, which are in agreement with the results of Markey et al. (1998). Therefore, the age discrepancies in Galway molybdenites in this study should not be attributed to analytical errors. Suzuki et al. (2000) revealed experimentally that the Re-Os system in molybdenite can behave as an open-system when immersed in warm aqueous $\mathrm{NaCl}$ or $\mathrm{NaHCO}_{3}$ bearing fluid. Detailed fluid inclusion studies of molybdenite vein quartz and granite quartz (Gallagher et al., 1992; O'Reilly et al., 1997) have shown that the Galway Granite was the locus for repeated fluid events, i.e., 1. Expulsion of aqueous carbonic magmatic fluids during the final stages of crystallization, 2. Meteoric fluid convection probably driven by waning magmatic heat and 3. Incursion of basinal brines associated with fluorite mineralization at least $100 \mathrm{Ma}$ after granite consolidation. We suggest that younger hydrothermal fluids perhaps associated with fluorite mineralization may have perturbed the Re-Os systematics of molybdenites from the Galway Granite.
\end{abstract}

\section{INTRODUCTION}

The Re-Os isotopic system is a useful tool for the direct determination of formation ages of sulfide ore deposits, because the chalcophile and siderophile properties of Re and Os lead to relatively high abundances of these elements in sulfide minerals, unlike such lithophile elements as $\mathrm{K}$ $\mathrm{Ar}, \mathrm{Rb}-\mathrm{Sr}, \mathrm{Sm}-\mathrm{Nd}$ and $\mathrm{U}-\mathrm{Pb}$ systems. Among the varieties of sulfide minerals, molybdenite $\left(\mathrm{MoS}_{2}\right)$ has been a target for the application of the Re-Os system because of its high concentration of Re
(Hintenberger et al., 1954; Fleischer, 1969).

To obtain an accurate age, it is necessary that the mineral has been kept closed for Re and Os since its formation. Luck and Allègre (1982) first presumed open-system behavior of Re in molybdenite. Suzuki et al. (1992, 1993, 1996), however, demonstrated that the age discrepancy may have resulted from analytical problems rather than geological open-system behavior. McCandless et al. (1993) examined molybdenite alteration in detail with regard to Re behavior. They reported that high transparency of 
molybdenite under near infrared (NIR) light and/or existence of certain secondary minerals indicated alteration and also Re loss in postdepositional alteration. Suzuki et al. (2000) experimentally demonstrated that disturbance of the Re-Os system depends on the alteration condition. On the contrary, Frei et al. (1998) claimed that the Re-Os system in molybdenite is resistant to alteration, and Stein et al. (1998a, b) demonstrated closed system behavior in molybdenite with a proper "whole molybdenite" mineral separation that is relatively fine-grained.

In this study, the Re-Os ages of molybdenite from the Galway granite, Ireland, were determined. The variation in the obtained Re-Os ages is discussed in the context of repeated hydrothermal fluid events that occurred both syn- and postconsolidation of the granite.

\section{Geological SeTting}

The Galway Granite batholith is exposed over an area of approximately $600 \mathrm{~km}^{2}$ along the north shore of Galway Bay; a southerly offshore extension of several $\mathrm{km}$ is indicated on gravity and aeromagnetic maps (Murphy, 1952; Max et al., 1983; Madden, 1987). It is a late-Caledonian "Itype" intrusion emplaced ca. $400 \mathrm{Ma}$ ago (Leggo et al., 1966) into the 474.5-462.5 Ma metagabbrogneiss suite (MGGS) to the north (Friedrich et al.,
1999), and into Lower Ordovician greenschist facies rocks (the South Connemara Group) to the south (McKie and Burke, 1955; Williams et al., 1988). The batholith is composed of lithologies that range from diorites through granodiorites and adamellites to alkali-feldspar granites (Leake, 1974, 1978; Max et al., 1978; El Desouky et al., 1996; Crowley and Feely, 1997).

Disseminated and quartz vein-hosted molybdenite mineralization occurs throughout the Galway Granite (Derham, 1986; Max and Talbot, 1986; Derham and Feely, 1988; Feely and Hoegelsberger, 1991; Gallagher et al., 1992; Derham, 1993). The most notable occurrences are at the western end of the batholith, i.e., at Mace Head and Murvey (Fig. 1). At Mace Head, molybdenite bearing quartz veins $(5-30 \mathrm{~cm}$ thick) trend NE-SW their orientation controlled by early jointing in the host granite (Derham, 1986; Max and Talbot, 1986). Additional vein minerals include chalcopyrite, pyrite, magnetite and muscovite. Mineralized and altered granite extends over an area of $2 \mathrm{~km}^{2}$ and in addition to the vein mineralization, quartz-magnetite pods and an intrusive K-feldspar breccia also occur (Derham and Feely, 1988). At Murvey, a highly evolved leucogranite contains molybdenite intergrown with muscovite. Quartz veins in the area also contain Mo-mineralization. Gallagher et al. (1992) interpreted the Mo-mineralization in both areas,

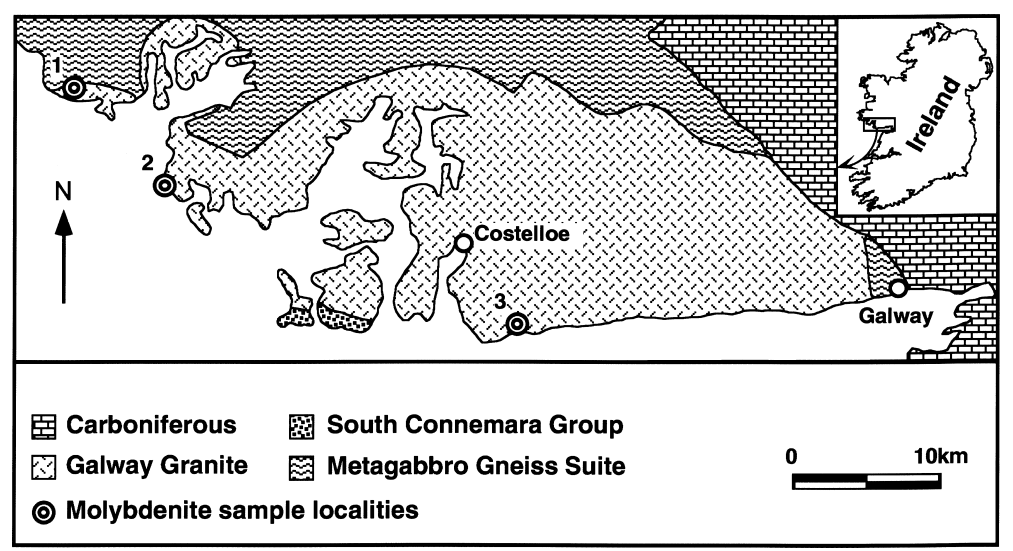

Fig. 1. Geological settings of the Galway Granite. Molybdenite sample localities are 1. Murvey, 2. Mace Head and 3. Travore Bay. 
using geochemical, fluid inclusion and stable isotope $(\mathrm{O}, \mathrm{H}, \mathrm{S}$ and $\mathrm{C})$ data, as having been produced by highly fractionated granite magma. Three localities were sampled in the Galway Granite, i.e., quartz vein-hosted molybdenite from Mace Head and Travore Bay, and granite-hosted molybdenite from Murvey (Fig. 1).

\section{Analytical Method}

Molybdenite samples were separated by handpicking from the quartz veins and granite. Os and Re abundances were determined by the isotope dilution method (Suzuki et al., 1992). Briefly, after Re and Os spikes were added, molybdenite was decomposed through the microwave digestion method. The decomposed solution was added with $\mathrm{K}_{2} \mathrm{Cr}_{2} \mathrm{O}_{7}$ to decompose molybdic acid and to completely oxidize Os to $\mathrm{OsO}_{4}$. Osmium was separated by distillation and Re was separated by anion exchange resin. An inductively coupled plasma mass spectrometer (ICP-MS), VG PQ2 ${ }^{\circledR}$ at the Institute of Physical and Chemical Research and VG PQ $3{ }^{\circledR}$ at the Institute for Geothermal Sciences were used for measurements of Os and $\mathrm{Re}$ isotope abundances. Mass discrimination in Os isotope measurement is corrected by a method modified from that of Hirata et al. (1988).

Recently, Markey et al. (1998) and Stein et al. (1997, 1998a) obtained a much higher precision $(10 \times)$ by employing alkaline fusion and negative thermal ionization mass spectrometry (NTIMS). Our study was undertaken through ICP-MS and, therefore, does not achieve precision levels currently possible with NTIMS. However, we believe the quality of the isotopic data presented is sufficient to justify the first-order conclusions presented in this paper.

\section{RESULTS AND DISCUSSION}

Because of the negligible quantity of common Os contained in the molybdenitea, model age can be obtained using the following equation:

$$
T=\left\{\ln \left[\left({ }^{187} \mathrm{Os} /{ }^{187} \mathrm{Re}\right)+1\right]\right\} / \lambda
$$

where $\lambda$ is the decay constant of ${ }^{187} \mathrm{Re}$ and equals to $(1.666 \pm 0.017) \times 10^{-11} \mathrm{yr}^{-1}($ Smoliar et al. 1996).

Re and Os abundances and the resultant ages for molybdenites are presented in Table 1 and Fig. 2. Molybdenites from the three localities in the Galway Granite yield the Re-Os ages of $425.2 \pm$ 3.1 Ma for Mace Head, $383.2 \pm 8.1$ and $426.1 \pm$ $5.5 \mathrm{Ma}$ for Murvey, and $338.9 \pm 5.6$ and $464 \pm 28$ Ma for Travore Bay. Previously, Hirt et al. (1963) analyzed the molybdenite sample from Murvey Granite and obtained the Re-Os age of $365 \pm 13$ Ma (recalculated using $\lambda\left({ }^{187} \mathrm{Re}\right)=1.666 \times 10^{-11}$ $\mathrm{yr}^{-1}$, Smoliar et al., 1996). Since molybdenites from the three localities were genetically related and were formed contemporaneously from the granitic magma (Gallagher et al., 1992), it is reasonable to expect that they would give harmonious Re-Os ages. However, the Re-Os ages obtained for each locality in this study and by Hirt et al. (1963) are not only inconsistent with the ages of the samples from the other localities but also are in disagreement even within each locality (Fig. $2)$. There are two reported ages of the host Galway Granite; the Rb-Sr age of $398 \pm 10 \mathrm{Ma}$ (Leggo et al., 1966, recalculated using $\lambda\left({ }^{87} \mathrm{Rb}\right)=1.42 \times$

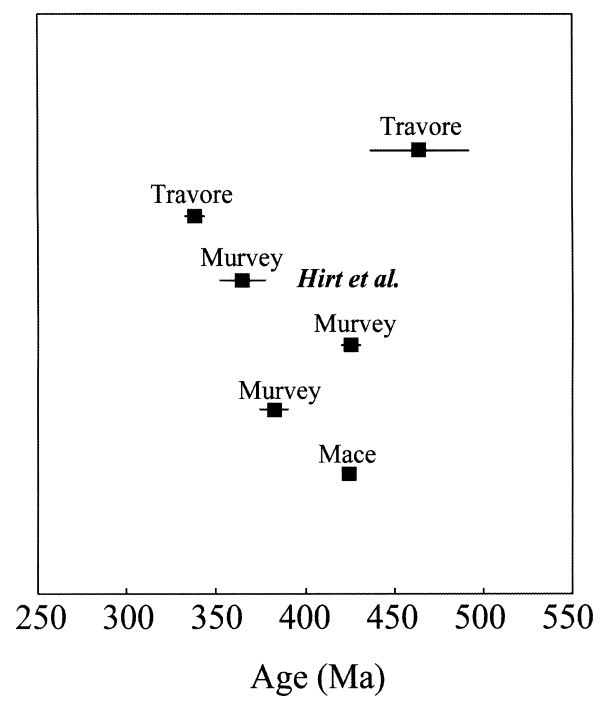

Fig. 2. Re-Os ages for molybdenites from Mace, Murvey, and Travore in the Galway Granite. The ReOs age obtained by Hirt et al. (1963) are also shown. 
Table 1. Results of Re and Os analysis of molybdenites from Galway, Ireland

\begin{tabular}{lccc}
\hline Sample & $\operatorname{Re}(\mathrm{ppb})$ & Os $(\mathrm{ppb})$ & Re-Os age (Ma) \\
\hline This study & & & \\
Galway Mace & $76140 \pm 360$ & $340.2 \pm 1.9$ & $425.2 \pm 3.1$ \\
Galway Murvey & $9492 \pm 42$ & $38.21 \pm 0.79$ & $383.2 \pm 8.1$ \\
& $10954 \pm 84$ & $49.05 \pm 0.51$ & $426.1 \pm 5.5$ \\
Galway Travore & $408.8 \pm 5.1$ & $1.455 \pm 0.016$ & $338.9 \pm 5.6$ \\
& $467 \pm 26$ & $2.281 \pm 0.061$ & $464 \pm 28$ \\
Hirt et al. (1963) & & & \\
Galway Murvey & $15200 \pm 400$ & $58.2 \pm 1.4$ & $365 \pm 13$ \\
\hline
\end{tabular}

Errors are $2 \sigma_{m}$.

Re-Os age calculations were based on the ${ }^{187}$ Re decay constant of $1.666 \times 10^{-11} \mathrm{yr}^{-1}$ (Smoliar et al., 1996).

Errors in all Re-Os ages do not include the 1.2\% uncertainty of the decay constant. The age obtained by Hirt et al. (1963) was also recalculated using Smoliar et al. (1996) ${ }^{187}$ Re decay constant.

$10^{-11} \mathrm{yr}^{-1}$ by Steiger and Jäger, 1977) and the U$\mathrm{Pb}$ age of $412 \pm 15 \mathrm{Ma}$ (on zircons, Pidgeon, 1969, recalculated using the decay constant of $U$ by Jaffey et al., 1971). However, since these data do not have enough quality available today and there is unusual statistical handling of data in $\mathrm{Rb}-\mathrm{Sr}$ age, we do not use these ages in our discussion.

The age discrepancies found in the Re-Os ages of molybdenites in this study are not the result of the analytical procedures followed in the present study. We made replicate analyses of a molybdenite "standard" (HLP-5) provided by the AIRIE group, Colorado State University. As shown in Table 2, our obtained Re-Os ages for HLP-5 (average 222.0 $\pm 2.1 \mathrm{Ma}, n=4$ ) reproduce within analytical errors for the ICP-MS method, and, in addition, agree with the results (221.3 \pm $0.24 \mathrm{Ma}, n=19)$ of Markey et al. (1998). These results illustrate the reliability of our technique for the Re-Os analysis of a powdered molybdenite standard, though precision of our ICP-MS age is 10 times greater than that of Markey et al. (1998) with NTIMS.

The range of Re-Os ages for molybdenites from the three localities in the Galway Granite may have been caused by post-ore deposition alteration accompanied by Re-Os fractionation. Frei et al. (1998) claimed that the Re-Os system in molybdenite was resistant to post-mineralization alteration and Stein et al. (1998a, b) demonstrate that the Re-Os chronometer in molybdenite is robust in a variety of different environments. In contrast, McCandless et al. (1993) reported that molybdenite might be susceptible to Re loss through hydrothermal alteration processes at temperatures as low as $150^{\circ} \mathrm{C}$, which affected Re-Os chronometry significantly. They determined the spatial Re distribution in altered rim (secondary minerals) and unaltered core of molybdenite and demonstrated evidence of Re remobilization at the boundary of the molybdenite mineral. In addition, Suzuki et al. (2000) demonstrated experimentally that the Re-Os system of molybdenite has an opensystem behavior in certain alteration conditions. They found that the molybdenite, which was exposed to $\mathrm{NaCl}$ and $\mathrm{NaHCO}_{3}$ solutions at a temperature of $180^{\circ} \mathrm{C}$ for 20 days, gave greatly deviated $\mathrm{Re}-\mathrm{Os}$ ages relative to that of the unaltered sample, especially in the outer part of the altered molybdenite. When the molybdenite was immersed in aqueous $\mathrm{AlCl}_{3}$ and $\mathrm{CaCl}_{2}$ solutions, it yielded an age consistent with the unaltered original molybdenite. Suzuki et al. (2000) claimed that, under similar conditions to the above, Re-Os fractionation would be triggered in molybdenite. These two papers showed that the Re-Os system of molybdenite could be disturbed by postdepositional alteration at least at a micro scale. On the other hand, Stein et al. (1998b) indicate reproducible $\mathrm{Re}-\mathrm{Os}$ ages for molybdenites by 
Table 2. Results of Re and Os analysis of molybdenite standard HLP-5, provided by the AIRIE group, Colorado State University

\begin{tabular}{cclc}
\hline Run & \multicolumn{1}{c}{ Re $(\mathrm{ppm})$} & ${ }^{187} \mathrm{Os}(\mathrm{ppb})$ & Re-Os age (Ma) \\
\hline 1 & $283.9 \pm 5.0$ & $661 \pm 12$ & $221.8 \pm 5.5$ \\
2 & $282.5 \pm 3.1$ & $663.0 \pm 3.3$ & $223.7 \pm 2.7$ \\
3 & $281.3 \pm 2.6$ & $652 \pm 13$ & $220.8 \pm 4.8$ \\
4 & $290.1 \pm 6.9$ & $673.9 \pm 4.7$ & $221.5 \pm 5.5$ \\
& & average & $222.0 \pm 2.1$ \\
$n=7$ & Stein et al. $(1997)$ & average & $221.5 \pm 0.3$ \\
$n=19$ & Markey et al. $(1998)$ & average & $221.3 \pm 0.2$ \\
\hline
\end{tabular}

Errors are $2 \sigma$.

Re-Os age calculations were based on the ${ }^{187}$ Re decay constant of $1.666 \times 10^{-11} \mathrm{yr}^{-1}$ (Smoliar et al., 1996).

Errors in our four Re-Os ages do not include the $1.2 \%$ uncertainty in the ${ }^{187}$ Re decay constant.

producing a sort of "whole-molybdenite" mineral separate, i.e., they collected all the molybdenites from a sample rock. They finely chop larger molybdenite crystals to produce a relatively finegrained mineral separate. Their procedure could cancel the effect of subtle within-crystal alteration on the Re-Os system. However, if the sample experienced intense alteration, where Re and/or ${ }^{187}$ Os have left the system, it might be dangerous to pulverize the whole sample at one time and produce sample powder, as Suzuki et al. (2000) suggested. The disturbed molybdenite would be mixed into unaltered, which leads to an erroneous age, though the Re-Os age would reproduce.

It is now well documented that the Galway Granite has experienced three major fluid events since its intrusion at ca. $400 \mathrm{Ma}$ (Feely and Hoegelsberger, 1991; Gallagher et al., 1992; O'Reilly et al., 1997). The earliest fluid to be trapped was a carbonic fluid of magmatic origin and was responsible for the molybdenite mineralization. The second fluid was a $\mathrm{H}_{2} \mathrm{O}-\mathrm{NaCl}-\mathrm{KCl}$, low-moderate salinity $(0-10 \mathrm{wt} \% \mathrm{NaCl}$ eq. $)$, moderate temperature $\left(270-340^{\circ} \mathrm{C}\right)$, high $\delta \mathrm{D}(-18 \pm$ $2 \%$ o), low $\delta^{18} \mathrm{O}(0.5-2.0 \%$ o) fluid of meteoric origin. The circulation of this fluid probably occurred as the batholith was cooling. The final fluid in- cursion involved low temperature $\left(\mathrm{ca} .150^{\circ} \mathrm{C}\right)$ basinal brines that deposited calcite-quartzfluorite and $\mathrm{Cu}-\mathrm{Pb}$ sulfide veins in the granite. This event took place at least $100 \mathrm{Ma}$ after granite consolidation and maybe as late as the Triassic, because field evidence reveals that these fluoritebearing veins cut a 300 Ma dolerite dyke which intruded the granite. Both the first and second fluids are never found in these late fluorite veins, while fluid inclusions from all three events occur in quartz samples from the molybdenite veins and mineralized granite (Feely and Hoegelsberger, 1991; Gallagher et al., 1992; O’Reilly et al., 1997).

Based on the above consideration, we suggest, in line with McCandless et al. (1993) and Suzuki et al. (2000), that the Re-Os system in molybdenite from the Galway Granite has been significantly perturbed by hydrothermal alteration associated with at the second and third pervasive hydrothermal fluid events. The inconsistent Re-Os age reported by Hirt et al. (1963) may also reflect this alteration, although the analytical errors in their neutron activation analyses and mass spectrometry cannot be ruled out. As shown in Fig. 2, the ReOs ages of molybdenite from Travore deviate the most significantly compared with the ages of the samples from Murvey and Mace, probably indicating the more intensive alteration. In addition, retrograde alteration of the granite (plagioclase to sericite, biotite and hornblende to chlorite \pm epidote, calcite and reddening of K-feldspars) are associated with the second and third fluid events. The results obtained in this study combined with the previous experimental studies provide evidence that hydrothermal fluids may be responsible for disturbance of the molybdenite Re-Os system.

\section{CONCLUSIONS}

Analytical results of $\mathrm{Re}$ and Os reveals that contemporaneous molybdenites from Mace, Murvey, and Travore in the Galway Granite give inconsistent Re-Os ages even within each locality. Fluid inclusion studies indicate that the 
molybdenites used in this study possibly experienced hydrothermal alteration after their deposition. These results allow us to suggest that the ReOs system in molybdenite may show open-system behavior during post-depositional exposure to hydrothermal fluids, and that these fluids represent an event of as yet uncertain age and origin. This hydrothermal event must be significantly younger than the age of molybdenite deposition in order to achieve the results presented in this paper, and could be related to much younger fluorite mineralization.

Acknowledgments - The authors are indebted to Bokuichiro Takano for his useful suggestions and to Kazuya Takahashi and Gen Shimoda for their instrumental support and to AIRIE group, Colorado State University, for providing their in-house molybdenite standard HLP-5. We would like to express our thankfulness to Wataru Ono for his suggestions and careful reading of the first draft of our manuscript. This manuscript was significantly improved by comments by Holly Stein, who does not necessarily endorse our interpretation. Review by Joaquin Ruiz and an anonymous referee are appreciated. We thank Typhoon Lee for editorial handling. This work was, partly, financially supported by the Grant-in-Aid (No. 09740403) for Fundamental Scientific Research from the Ministry of Education, Science, Sports and Culture of Japan, and the TOYOTA FOUNDATION.

\section{REFERENCES}

Crowley, Q. and Feely, M. (1997) New perspectives on the order and style of granite emplacement in the Galway Batholith, western Ireland. Geol. Mag. 134, 539-549.

Derham, J. M. (1986) Structural control of sulphide mineralization at Mace Head, Co. Galway. Geology and Genesis of Mineral Deposits in Ireland (Andrew, C. J., Crowe, R. W. A., Finlay, S., Pennell, W. M. and Pyne, J. F., eds.), 187-193, Irish Ass. Econ. Geol.

Derham, J. M. (1993) The geology and genesis of the Mace Head molybdenite deposit, Carna, Co. Galway, Ireland. Ph.D. Thesis, National University of Ireland.

Derham, J. M. and Feely, M. (1988) A K-feldspar breccia from the Mo-Cu stockwork deposit in the Galway Granite, west of Ireland. J. Geol. Soc. London 145, 661-667.

El Desouky, M., Feely, M. and Mohr, P. (1996) Dioritegranite magma mingling and mixing along the axis of the Galway Granite batholith, Ireland. J. Geol. Soc. London 153, 361-374.

Feely, M. and Hoegelsberger, H. (1991) Preliminary fluid inclusion studies of the Mace Head Mo-Cu deposit in the Galway Granite. Irish J. Earth Sci. 11, 1-10.

Fleischer, M. (1969) The geochemistry of rhenium, with reference to the occurrence in molybdenite. Econ. Geol. 54, 1406-1413.

Frei, R., Nagler, T. F., Schonberg, R. and Kramers, J. D. (1998) Re-Os, Sm-Nd, U-Pb, and stepwise lead leaching isotope systematics in shear-zone hosted gold mineralization: Genetic tracing and age constraints of crustal hydrothermal activity. Geochim. Cosmochim. Acta 62, 1925-1936.

Friedrich, A. M., Bowring, S. A., Martin, M. W. and Hodges, K. V. (1999) Short-lived continental magmatic arc at Connemara, western Irish Caledonides: Implications for the age of the Grampian orogeny. Geology 27, 27-30.

Gallagher, V., Feely, M., Hoegelsberger, H., Jenkin, G. R. T. and Fallick, A. E. (1992) Geological, fluid inclusion and stable isotope studies of Mo mineralization, Galway Granite, Ireland. Mineral. Dep. 27, 314325.

Hintenberger, W., Herr, W. and Voshage, H. (1954) Radiogenic osmium from rhenium-containing molybdenite. Phy. Rev. 95, 1690-1694.

Hirata, T., Shimizu, H., Akagi, T. and Masuda, A. (1988) Simultaneous determination of isotopic ratio and abundance of osmium by ICP-MS: fundamental studies for the application to rhenium-osmium systematics. ICP Inf. Newslett. 13, 731-735.

Hirt, B., Herr, W. and Hoffmeister, W. (1963) Age determination by the rhenium-osmium method. Intern. Atomic Energy Agency, Radioactive Dating, 35-44.

Jaffey, A. H., Flynn, K. F., Glendenin, L. F., Bentley, W. C. and Essling, A. M. (1971) Precision measurements of half-lives and specific activities of ${ }^{235} \mathrm{U}$ and ${ }^{238}$ U. Phys. Rev. C4, 1889-1906.

Leake, B. E. (1974) The crystallisation history and mechanism of emplacement of the western part of the Galway Granite, Connemara, western Ireland. Mineral. Mag. 39, 498-513.

Leake, B. E. (1978) Granite emplacement. The granites of Ireland and their origin. Crustal Evolution in Northwest Britain and Adjacent Regions. Geol. J. Special Issue (Bowes, D. R. and Leake, B. E., eds.), 10, 221-248.

Leggo, P. J., Compston, W. and Leake, B. E. (1966) The geochronology of the Connemara granites and its bearing on the antiquity of the Dalradian Series Q. J. Geol. Soc. London 122, 91-118.

Luck, J. M. and Allègre, C. J. (1982) The study of 
molybdenite through the ${ }^{187} \mathrm{Re}^{187}$ Os chronometer. Earth Planet. Sci. Lett. 61, 290-296.

Madden, J. S. (1987) Gamma-ray spectrometric studies of the main Galway Granite, Connemara, west of Ireland. Ph.D. Thesis, National University of Ireland.

Markey, R., Stein, H. and Morgan, J. (1998) Highly precise Re-Os dating for molybdenite using alkaline fusion and NTIMS. Talanta 45, 935-946.

Max, M. D. and Talbot, V. (1986) Molybdenum concentrations in the western end of the Galway Granite and their structural setting. Geology and Genesis of Mineral Deposits in Ireland (Andrew, C. J., Crowe, R. W. A., Finlay, S., Pennell, W. M. and Pyne, J. F., eds.), 177-185, Irish Ass. Econ. Geol.

Max, M. D., Long, C. B. and Geoghegan, M. (1978) The Galway Granite. Bull. Geol. Surv. Ireland 2, 223233.

Max, M. D., Ryan, P. D. and Inamdar, D. D. (1983) A magnetic deep structural geology interpretation of Ireland. Tectonics 2, 431-451.

McCandless, T. E., Ruiz, J. and Campbell, A. R. (1993) Rhenium behavior in molybdenite in hypogene and near-surface environments: Implications for Re-Os geochronometry. Geochim. Cosmochim. Acta 57, 889-905.

McKie, D. and Burke, K. (1955) The geology of the islands of south Connemara. Geol. Mag. 92, 487498.

Murphy, T. (1952) Measurements of gravity in Ireland: Gravity survey of central Ireland. Dublin Inst. Adv. Studies, Geophys. Mem. 2.

O'Reilly, C., Jenkin, G. R. T., Feely, M., Alderton, D. H. M. and Fallick, A. E. (1997) A fluid inclusion and stable isotope study of $200 \mathrm{Ma}$ of fluid evolution in the Galway granite, Connemara, Ireland. Mineral. Petrol. 129, 120-142.

Pidgeon, R. T. (1969) Zircon U-Pb ages from the Galway granite and the Dalradian, Connemara, Ireland. Scott. J. Geol. 5, 375-392.

Smoliar, M. I., Walker, R. J. and Morgan, J. W. (1996) $\mathrm{Re}-\mathrm{Os}$ ages of group IIA, IIIA, IVA, and IVB iron meteorites. Science 271, 1099-1102.
Steiger, R. H. and Jäger, E. (1977) Subcommission on geochronology: Convention on the use of decay constants in geo- and cosmochronology. Earth Planet. Sci. Lett. 36, 359-362.

Stein, H. J., Markey, R. J., Morgan, J. W., Du, A. and Sun, Y. (1997) Highly precise and accurate Re-Os ages for molybdenite from the East Qinling molybdenum belt, Shaanxi Province, China. Econ. Geol. 92, 827-835.

Stein, H. J., Sundblad, K., Markey, R. J., Morgan, J. W. and Motuza G. (1998a) Re-Os ages for Archean molybdenite and pyrite, Kuittila-Kivisuo, Finland and Proterozoic molybdenite, Kabeliai, Lithuania: Testing the chronometer in a metamorphic and metasomatic setting. Mineral. Dep. 33, 329-345.

Stein, H. J., Morgan, J. W., Markey, R. J. and Hannah, J. L. (1998b) An introduction to Re-Os: What's in it for the mineral industry. SEG Newslett. 32, 1, 8-15.

Suzuki, K., Qi-Lu, Shimizu, H. and Masuda, A. (1992) Determination of osmium abundance in molybdenite mineral by isotope dilution mass spectrometry with microwave digestion using potassium dichromate as oxidizing agent. Analyst 117, 1151-1156.

Suzuki, K., Qi-Lu, Shimizu, H. and Masuda, A. (1993) Reliable Re-Os age for molybdenite. Geochim. Cosmochim. Acta 57, 1625-1628.

Suzuki, K., Shimizu, H. and Masuda, A. (1996) Re-Os dating of molybdenites from ore deposits in Japan; implication for closure temperature of Re-Os system for molybdenite and cooling history of molybdenum ore deposits. Geochim. Cosmochim. Acta 60, 31513159.

Suzuki, K., Kagi, H., Nara, M., Takano, B. and Nozaki, Y. (2000) Experimental alteration of molybdenite: Evaluation of the Re-Os system, infrared spectroscopic profile and polytype. Geochim. Cosmochim. Acta 64, 223-232.

Williams, D. M., Armstrong, M. A. and Harper, D. A. T. (1988) The age of the South Connemara Group, Ireland, and its relationship to the Southern Uplands Zone of Scotland and Ireland. Scott. J. Geol. 24, 279287. 